\title{
CIVIL CONTROL OVER THE ACTIVITY OF THE SUBJECTS OF PUBLIC ADMINISTRATION
}

\author{
Maslova Ya. I., Savchuk R. M.
}

\section{INTRODUCTION}

In the conditions of the necessary implementation of the concept of «participatory democracy» and intensification of tendencies of decentralization of state power in Ukrainian, state management acquired new features and became public administration, with characteristic features of wide public involvement and service purpose of the state. The effective participation of a wide range of representatives of various social spheres - politics, government institutions, scientific and expert community, civic associations in the implementation of public administration, turns it into a complex process of finding common solutions and reaching consensus. Today, the main problems are the correlation between administration and management, the functioning of the subjects of public administration in accordance with the principles of the rule of law and good governance, the establishment of interaction between civil society institutions and the subjects of public administration.

The signing of the Association Agreement between Ukraine and the European Union in 2014 activated the process of intensifying the effectiveness of civil society institutions in Ukraine ${ }^{1}$. As stated in the National Strategy for Civil Society Development in Ukraine for 2016-2020, its adoption «is caused by the need for the state to create favourable conditions for civil society development, various forms of participatory democracy, effective public interaction with public authorities and local governments» ${ }^{2}$.

Thus, in accordance with the National Strategy for Civil Society Development in Ukraine for 2016-2020, systematic state support for civil society should be provided in order to create favourable conditions for the formation and institutional development of civil society organizations (improvement of legal status, establishment, organization and termination of bodies of self-organization of the population, expanding their powers to

\footnotetext{
1 Угода про асоціацію між Україною, з однієї сторони, та ЄС, Європейським співтовариством 3 атомної енергії і їхніми державами-членами, з іншої сторони: Міжнародний документ від 27.06.2014 p. Дата оновлення від 30.11.2015 p. URL: https://zakon.rada.gov.ua/laws/show/984_011.

2 Про сприяння розвитку громадянського суспільства в Україні: Указ Президента України від 26.02.2016 p. № 68/2016. Дата оновлення від 26.02.2016 p. URL: https://zakon.rada.gov.ua/ laws/show/68/2016.
} 
participate in addressing issues of local importance, the legislative level of mandatory planning in the State Budget of Ukraine and local budgets of expenditures for providing financial support on a competitive basis for programs (projects, activities) developed by civil society organizations society, etc.).

However, the state of interaction between state authorities and local self-government bodies with the public remains low and inefficient due to the lack of appropriate support mechanisms. Under such conditions, it is important for civil society institutions to monitor the activities of public administration entities. Moreover, this type of control is a way of providing «feedback», as its consequences can be used by authorized entities to assess the quality and effectiveness of their functional purpose.

\section{Institutional and legal principles of civil control over the activities of the subjects of public administration}

Democratic transformation in Ukraine is directly or indirectly linked to the involvement of civil society institutions in the public administration. The definition of civil society is not unambiguous, it varies: depending on the field of scientific knowledge, the legal system within which civil society operates, the socio-cultural archetypes that have developed and other features. In general, it is possible to distinguish a broad approach to the interpretation of the concept of «civil society», whose supporters define it as a qualitative stage of society, which has reached a qualitatively high level of self-organization, democracy, human and civil rights and freedoms ${ }^{3}$. At the same time, the forms of public participation in public administration differ and acquire distinctive features depending on the rights granted to citizens. According to the Constitution of Ukraine, every citizen is guaranteed the right to freedom of thought and speech, to freely express their views and beliefs (Article 34), the right to freedom of association in political parties and public organizations to exercise and protect their rights and freedoms and satisfaction political, economic, social, cultural and other interests (Article 36), the right to participate in the management of state affairs, in all-Ukrainian and local referendums, to freely elect and be elected to public authorities and local self-governments (Article 38), the right to file individual or collective written appeals or personally apply to public authorities, local governments, officials and functionaries of these bodies and a number of other rights and freedoms, which are ensured by a set of appropriate

${ }^{3}$ Соляр С. Громадянське суспільство: загальнотеоретичні підходи до визначення. Вісник Академії правових наук України. 2013. № 1. Ст. 271-279 
measures ${ }^{4}$. That is, ways of exercising the rights granted to the public are the forms of participation of these subjects in public administration.

With regard to civil control over the activities of the subjects of public administration as a form of participation in public administration, it can be implemented through the establishment and operation of public (expert) councils in the activities of the subjects of public administration; conducting a public examination of the activities of public authorities; conducting anticorruption public examination of the activities of the subjects of public administration; ensuring the possibility of citizens' appeals to the subjects of public administration, etc. These forms of participation of civil society institutions in the implementation of public administration take place in the legal reality in the Ukrainian state. However, those forms of participation that are not grounded by specific measures of legal responsibility (for example, holding public consultations does not imply the obligation to take into account public opinion de facto), are not properly effective. Also, the low general standard of living in Ukraine does not allow to take the opportunity to apply to the subjects of public administration through electronic means of communication. In addition to these obvious shortcomings in the interaction between civil society institutions and the subjects of public administration, there are a number of gaps associated with corruption risks, low levels of legal awareness of citizens, outdated archetypes of state management, and so on.

In general, control is a term that reflects the observance of the rule of law in specific social relations with its specific composition. The effectiveness of control is mediated by the quality of the public administration. Control in a broad sense can be defined as the activity of ensuring the compliance of the state of the managed entity with the management decision and compliance of the functioning of the entity with the statements of law.

The theory of administrative law identifies the following specifications for the use of the term «control» in the functioning of civil society:

1) control is a function of civil society, the essence of which is the timely identification and elimination of factors that impede the effective implementation of human and civil rights and freedoms and make it impossible to ensure the proper level of law enforcement;

2) control is a function of a specific institution of civil society, the essence of which is indirectly enshrined in the statutory status of the

${ }^{4}$ Конституція України: Закон України від 02.10.1996 р. Із змінами, внесеними Законом України від 08.12.2004 р. № 2222-IV. Дата оновлення 01.01.2020 p. URL: http://zakon2.rada.gov.ua/ laws/show/254\%D0\%BA/96-\%D0\%B2\%D1\%80. 
subject and which is characterized by a set of specific rights to prompt and continuous prevention, detection and elimination of factors causing deviations in a specific area of human and civil rights and freedoms;

3) control is a specific activity, the essence of which is the active interaction of the public with the subject of public administration, carried out on the basis of legality, efficiency, economy, expediency, professional validity, aimed at achieving human and civil rights and freedoms;

4) control is a system of observations and inspections, the essence of which is to establish compliance of the state of the object that is subject to control with the rules (management decision), the separation of deviations from these rules, as well as deviations from the general principles of organization and regulation;

5) control is a means of ensuring legality in the activities of public administration, the essence of which is realized through a special system of public authorities and civil society institutions, which is responsible for maintaining and strengthening legality and discipline in the activities of the subject of power.

Each of these definitions of the use of the term «control» is correct, and the difference between them is manifested in the choice of a feature of the functioning of civil society, which is determined through control.

The purpose of civil control over the activities of public administration is: to ensure the appropriate level of human and civil rights and freedoms; acquisition of objective information on the state of compliance with the law in the field of public administration; research of the acquired information for the purpose of revealing and the termination of the facts of infringements of the current legislation, establishment of the reasons and conditions promoting their commission; comparison of achieved results with previous and expected ones; prevention of new violations and harmful consequences in the field of law enforcement; identification of persons guilty of violating the proper state of public administration, etc.

Civil control allows to identify and eliminate in a timely manner the factors that hinder the effective implementation of human and civil rights and freedoms, making it impossible to ensure the appropriate level of law enforcement. The features of control as a functional expression of the functioning of civil society include the following:

1) public nature, which is ensured by exercising control on behalf and in the interests of the person on the basis of the application of the rights granted to citizens by law;

2) legality, which is expressed in the normatively enshrined powers of the public to carry out activities, the content of which is control; 
3) objectivity, which is manifested in the independence and impartiality of civil society institutions in carrying out activities aimed at achieving control;

4) comprehensiveness, which is provided by the assessment of the activities of the controlled entity from the standpoint of legality, expediency, efficiency;

5) ensuring the possibility of citizen intervention in the activities of the controlled entity through the institution of citizens' appeals, etc.

Civil control is a type of public control exercised by civil society institutions. Civil society exists with the active participation of citizens in the management of public and state affairs. This norm is a principle, as well as an intermediate goal of public administration. Therefore, the signs of civil control over the activities of public administration as a specific form of control include:

1) the subject of civil control is citizens and public associations that are organizationally and functionally independent of the objects of control;

2) the object of civil control is the sphere of public administration;

3 ) the purpose of civil control is to ensure the public interest;

4) civil control is exercised exclusively in the forms provided by law;

5 ) is provided with moral and legal measures of influence;

6) the results of civil control may be the basis for the exercise of other types of civil control provided by state coercion.

Thus, civil control over the activities of public administration entities is the activity of the public (individuals and (or) public associations), which is the active interaction of the public with the subject of public administration through a system of observations and inspections to establish compliance of the object, which is subject to control by the applied instruments of public administration, and which is aimed at achieving the goal of proper provision of human and civil rights and freedoms in the field of public administration.

\section{Appeals of citizens as a form of civil control over the activities of public administration}

The main form of civil control over the activities of public administration is the right of citizens to file individual or collective written appeals or personally apply to public authorities, local governments and officials of these bodies, which are obliged to consider appeals and give a reasoned response within the statutory period, which is enshrined in Article 40 of the Constitution of Ukraine ${ }^{5}$. This constitutional right also provides for the possibility to submit to public authorities' proposals to improve the

${ }^{5}$ Конституція України: Закон України від 02.10.1996 р. Із змінами, внесеними Законом України від 08.12.2004 p. № 2222-IV. Дата оновлення 01.01.2020 p. URL: http://zakon2.rada.gov.ua /laws/ show $/ 254 \%$ D0 $\%$ BA/96- $\%$ D0\%B2\%D1\%80. 
effectiveness and efficiency of their activities, and comments, to appeal their decisions, actions or omissions, and so on.

In the context of adaptation of domestic legislation to the standards of the European Union, international regulations become important, on the basis of which the legal basis for consideration and resolution of citizens' appeals is determined. It is seen that the consolidation of the institution of appeals in international regulations is caused by the need to provide certain guarantees for the strict implementation of existing laws by all members of society. Such basic international regulations should include such as:

Universal Declaration of Human Rights of December 10, 1948 - this document provides that everyone has the right to: the effective restoration of rights by the competent national courts in the case of violation of his fundamental rights granted to him by the constitution or law (Article 8); freedom of belief and freedom of expression, which includes the freedom to freely adhere to one's beliefs and the freedom to seek, receive and impart information and ideas by any means and regardless of frontiers (art. 19); participation in the governance of their country (Article 21) ${ }^{6}$;

Convention for the Protection of Human Rights and Fundamental Freedoms of November 4, 1950 -Article 34 provides for the exercise of the right to appeal, according to which persons have the right to apply to the court in case of violation of their rights ${ }^{7}$;

The International Covenant on Civil and Political Rights of 16 December 1966 - stipulates that each State Party undertakes to provide: an effective remedy, even if the violation has been committed by persons acting as officials; that the right to legal protection for any person in need of such protection be established by the competent judicial, administrative or legislative authorities, or by any other competent body provided for by the legal system of the State, to develop possibilities for judicial protection, etc ${ }^{8}$;

The Charter of Fundamental Rights of the European Union of 7 December 2000 - provides that every citizen of the Union, or a natural or legal person residing or having a registered office in a Member State, may submit petitions to the European Parliament for the exercise of the right of appeal (Art. 44) ${ }^{9}$.

\footnotetext{
${ }_{6}^{6}$ Загальна декларація прав людини: Міжнародний документ від 10.12.1948 p. URL: http://zakon4.rada.gov.ua/laws/show/995_015.

7 Конвенція про захист прав людини і основоположних свобод: Міжнародний документ від 04.11.1950 p. URL: http://zakon2.rada.gov.ua/laws/show/995_004.

${ }^{8}$ Міжнародний пакт про громадянські і політичні права: Міжнародний документ від 16.12.1966 p. URL: https://zakon.rada.gov.ua/laws/show/995_042.

9 Хартія основних прав Європейського Союзу: Міжнародний документ від 07.12.2000 p. URL: http://zakon2.rada.gov.ua/laws/show/994_524.
} 
Issues of practical implementation of the right of citizens to make proposals to public authorities, associations of citizens in accordance with their statutes to improve their activities, expose shortcomings in work, challenge the actions of officials of state and municipal bodies are regulated by the Law of Ukraine «On Citizens' Appeals». types of citizens' appeals, such as:

a) proposal and/or remarks - an appeal expressing advice, recommendation on the activities of public authorities and local governments, deputies of all levels, officials, as well as opinions on the regulation of public relations and living conditions of citizens, improving the legal basis of state and public life, socio-cultural and other spheres of activity of the state and society;

b) application - a request containing a request to promote the implementation of the rights and interests of citizens enshrined in the Constitution and current legislation or notification of violations of current legislation or shortcomings in the activities of enterprises, institutions, organizations regardless of ownership, deputies of Ukraine, local councils, officials, as well as expressing an opinion on improving their activities;

c petition - a written request for recognition of the relevant status, rights or freedoms ${ }^{10}$;

d) complaint - a form of civil control over the activities of public authorities in general, and individual officials or officials in particular, through which the demand of citizens to restore the violated right.

Selected types of appeals, in their entirety, or separately, perform a specific functional purpose. In a general sense, the functions of the right of appeal are the main directions of legal influence on public relations, reflecting their role and purpose in regulating the latter and carried out by appropriate means to properly implement and protect the rights, freedoms and legitimate interests of citizens ${ }^{11}$.

Issues of record keeping on proposals (comments), applications (petitions) and complaints of citizens are regulated by the Instruction on record keeping on appeals of citizens in public authorities and local governments, associations of citizens, enterprises, institutions, organizations regardless of ownership, in the mass media ${ }^{12}$.

\footnotetext{
${ }^{10}$ Про звернення громадян: Закон України від 02.10.1996 р. Дата оновлення 01.01.2020 p. URL: https://zakon2.rada.gov.ua/laws/show/393/96-\%D0\%B2\%D1\%80.

${ }^{11}$ Костюкевич О.К. Про функції права громадян на звернення. Право і Безпека. 2009. № 1. C. 195 .

12 Про затвердження Інструкції з діловодства за зверненнями громадян в органах державної влади і місцевого самоврядування, об'єднаннях громадян, на підприємствах, в установах, організаціях незалежно від форм власності, в засобах масової інформації: Постанова Кабінету Міністрів України від 14.04.1997 № 348. URL: https://zakon.rada.gov.ua/laws/ show $/ 348-97-\%$ D0\% BF.
} 
Regarding the complaint as a kind of citizens appeals, aimed at identifying and terminating violations of current legislation, establishing the causes and conditions that contribute to their commission, as well as preventing new violations and harmful consequences in the law, the following aspects of its provision should be considered.

The study of the legal nature of a complaint against the actions or decisions of a subject of power must first begin with the definition of the individual categories that make it up. In lexical terms, «complaint» is interpreted as: 1) expression of dissatisfaction, reprimand; 2) an official written or oral statement about illegal or incorrect actions of any person, institution and others. In the legal encyclopedia Yu.S. Shemshuchenko, a complaint is defined as a form of appeal of a natural or legal person to the relevant state authority or local government body, official and functionary of these bodies with a statement to restore the violated rights of complainants and protect their legitimate interests ${ }^{13}$. In Art. 3 of the Law of Ukraine «On Citizens' Appeals» the complaint is a request to restore the rights and protect the legitimate interests of citizens violated by actions (inaction), decisions of state bodies, local governments, enterprises, institutions, organizations, associations of citizens, officials ${ }^{14}$.

Based on the analysis of these definitions of the concept of «complaint» it seems to be possible to distinguish its essential features, which include the following:

1) the purpose of filing a complaint is a requirement to restore the rights and protect the legitimate interests of citizens;

2) the subject of the appeal is a citizen of Ukraine (or persons who are not citizens of Ukraine, but legally reside on its territory, unless otherwise is provided by international agreements);

3) the object of the complaint is the appeal of actions (inaction) or the decision of the subject of power. The subject of power should be understood as a body of state power (including bodies without the status of a legal entity), local government, their official or functionary, another subject in the exercise of public authority management functions on the basis of legislation, including to perform delegated powers, or to provide administrative services ${ }^{15}$.

Citizens' complaints about actions (inaction) or decisions of the subject of power are a form of civil control over the activities of public authorities

${ }_{13}$ Юридична енциклопедія: в 6 т. / за заг. ред. Ю.С. Шемшученко. Київ: «Укр. енцикл.», 2002. Т. 4: Н-П. 720 c. URL: http://leksika.com.ua/legal/.

${ }^{14}$ Про звернення громадян: Закон України від 02.10.1996 р. Дата оновлення 01.01.2020 p. URL: https://zakon2.rada.gov.ua/laws/show/393/96-\%D0\%B2\%D1\%80.

15 Кодекс адміністративного судочинства України: Закон України від 6.07.2005 p. № 2747-IV. Дата оновлення 13.02.2020 p. URL: https://zakon.rada.gov.ua/laws/show/2747-15/conv. 
in general, and individual officials or functionaries in particular, which expresses the demand of citizens to restore the violated right. In addition, the possibility of appealing to public authorities with a legal requirement contributes to the formation of legal awareness of citizens, which is the key to the formation of civil society.

The importance of the right to file a complaint is also that it is a kind of information channel that connects public authorities and citizens. The right to appeal to these bodies, on the one hand, is a way of expressing public opinion, and on the other - a means of obtaining information from the authorities about the quality and shortcomings of their work ${ }^{16}$.

Examining the legal nature of citizens' complaints about actions (inaction) or decisions of the subject of power, it is necessary to determine the participants in the legal relationship that arises when filing the relevant complaints. On the basis of theoretical researches, the current legislation, it is possible to specify four groups of subjects of proceedings on appeals of citizens in the form of the complaint ${ }^{17}$ :

- the first group consists of subjects who apply - these are legally capable citizens of Ukraine, foreigners and stateless persons who reside on the territory of the state on legal grounds;

- the second group is the persons considering the appeal. This type includes entities that consider appeals and make decisions based on them. These are: public authorities; local governments; enterprises, institutions, organizations; citizens' associations; mass media;

- the third group - the subjects that facilitate the consideration of the complaint - belong to the persons who provide information to make an informed decision. The current legislation does not provide for a list of such persons, however, analyzing the Law of Ukraine «On Citizens' Appeals», it is seen that such entities are a representative of the organization, a representative of the workforce, persons who violated the rights of persons providing information to competent authorities during the verification of appeals. The peculiarity of this group of subjects is that their competence is realized at the stage of consideration of the complaint ${ }^{18}$;

- the fourth group - representatives, i. e. persons who are authorized to file a complaint in the interests of the citizen. The peculiarity of this type of

\footnotetext{
${ }^{16}$ Цимбалюк В.М. Сутність права громадян на звернення до публічної адміністрації. Право і суспільство. № 2. 2012. С. 91.

17 Цимбалюк В.І., Кісілевич К.О. Звернення громадян як важлива складова захисту прав і свобод людини та громадянина в Україні. Молодий вчений. № 5.1 (45.1). 2017. С. 149-150.

${ }^{18}$ Стеценко С.Г. Адміністративне право України. Навч. посібник. Київ: Атіка, 2007. с. 123.
} 
participants is that their competence is realized at the stage of application. This group of entities includes: lawyers, legal representatives of minors and incapacitated persons, labour collectives, human rights organizations, and other authorized persons.

Complaint as a form of appeal seems to be possible to classify depending on various criteria into the following types:

1) depending on the method of submission: a) a complaint sent by mail; b) personal submission by a citizen to the relevant body, institution; c) through a representative whose powers are formalized in accordance with the law; d) sending using the Internet, electronic means of communication;

2) depending on the sign of receipt: a) primary; b) repeated;

3) for the subject of submission: a) individual; b) collective; c) anonymous;

4) depending on the form: a) oral; b) written;

5) depending on the complainant: a) general: citizens of Ukraine, foreigners and stateless persons who are legally on the territory of the state; b) special: a participant in the war; child of war; invalid of the Great Patriotic War; war invalid; participant in hostilities; labour veteran; disabled person of the I group; disabled person of the II group; disabled person of group III; a child with a disability; single mother; mother-heroine; large family; a person affected by the Chernobyl disaster; participant in the liquidation of the consequences of the Chernobyl accident; Hero of Ukraine; Hero of the Soviet Union; Hero of Socialist Labour; child; other categories.

6) depending on the consequences of the review: a) the decision on the results of the complaint is made in favour of the complainant; b) denied consideration; c) the decision is made in favour of the subject of power.

Any complaint is considered in the manner prescribed by the Law of Ukraine «On Citizens' Appeals». The refusal to accept a complaint against the actions or decisions of the subject of power by a public authority is prohibited. The complaint is registered on the day of its submission or receipt by a public authority, but not later than the next working day ${ }^{19}$.

A person who complains about the actions (inaction) or decision of the subject of power is intended to restore the violated right or legitimate interest. As a result, the question arises as to the possibility of a person's deterioration as a result of a decision on his or her application. It is considered inadmissible to use an appeal (complaint) to the detriment of the person who filed it, or in whose interests it was filed.

\footnotetext{
19 Про затвердження Інструкції з діловодства за зверненнями громадян в органах державної влади і місцевого самоврядування, об’єднаннях громадян, на підприємствах, в установах, організаціях незалежно від форм власності, в засобах масової інформації: Постанова Кабінету Міністрів України від 14.04.1997 № 348. URL: https://zakon.rada.gov.ua/laws/show/348-97-\%D0\% BF.
} 
In order to prevent a situation in which a complaint may be considered in violation of applicable law, which, as a consequence, will not lead to the restoration of violated rights, but deterioration of the person, according to the Law of Ukraine «On Citizens' Appeals» the subjects that consider such an appeal have such responsibilities as, in particular ${ }^{20}$ :

- the need to adhere to the principles of objectivity, comprehensiveness and timeliness when examining and resolving an application or complaint;

- in the case of a decision to restrict a citizen's access to relevant information when considering an application or complaint to make a reasoned decision;

- at the request of a citizen to invite him to a meeting of the relevant body that considers his application or complaint;

- cancel or change the appealed decisions in cases provided by the legislation of Ukraine, if they do not comply with the law or other regulations, immediately take measures to stop illegal actions, identify, eliminate the causes and conditions that contributed to the violation;

- to ensure the restoration of violated rights, the actual implementation of decisions taken in connection with the application or complaint;

- to inform the citizen in writing about the results of the verification of the application or complaint and the essence of the decision made;

- take measures to compensate in the manner prescribed by law for material damage, if they were caused to a citizen as a result of infringement of his rights or legitimate interests, to address the liability of persons for whom the violation was committed, as well as at the request of the citizen within one month the decision is made to the notice of the local selfgovernment body, labour collective or association of citizens at the place of residence of the citizen, etc.

Summarizing the above-mentioned, we conclude that the right to complain about the actions (inaction) or decision of the subject of power plays a significant role in democratizing the political and social order, provides a link between the state and citizens, and performs an important function of control over the activities of the subjects of public administration.

In general, the submission of applications, complaints and proposials by citizens to the subjects of power in general affects the effectiveness and efficiency of the latter. To study the mechanism of the impact of citizens' appeals on the effectiveness and efficiency of public administration, it is necessary to define the categories of «effectiveness» and «efficiency».

${ }^{20}$ Про звернення громадян: Закон України від 02.10.1996 р. Дата оновлення 01.01.2020 p. URL: https://zakon2.rada.gov.ua/laws/show/393/96-\%D0\%B2\%D1\%80. 
In the lexical sense, the term «effectiveness» refers to the ability of the subject to achieve certain results. Thus, the effectiveness of the subjects of power is the degree of conformity of the achieved results in the exercise of public authority management functions on the basis of legislation, including the implementation of delegated powers, or the provision of administrative services. Analysis of the effectiveness of official activities of the subjects of power involves determining the achievement of planned results, namely: the completeness of duties during the reporting period in accordance with the provisions of job descriptions, the level of complexity of tasks, demonstrated knowledge, skills, professional and personal competencies, compliance with the rules of ethical conduct and integrity, internal official regulations.

Thus, based on the results of consideration and resolution of citizens' appeals, the performance of a particular subject of power is evaluated, which provides for the planned activities of individual citizens aimed at monitoring the quality of certain tasks over a period of time, in particular to obtain expected results. Instead, the effectiveness of certain actions should be understood as their logical completion, which contributes to achieving the expected results.

With regard to the consideration of citizens' appeals, the activity on the part of the subjects of power may be considered effective if they perform in full the obligations specified in Art. 19 of the Law of Ukraine «On Citizens" Appeals», in particular such as: objectively, comprehensively and timely check applications or complaints; in the case of a decision to restrict a citizen's access to relevant information when considering an application or complaint to make a reasoned decision; cancel or change the appealed decisions in cases provided by the legislation of Ukraine, if they do not comply with the law or other regulations, immediately take measures to stop illegal actions, identify, eliminate the causes and conditions that contributed to the violation; to ensure the restoration of violated rights, the actual implementation of decisions taken in connection with the application or complaint; to inform the citizen in writing about the results of the verification of the application or complaint and the essence of the decision made; take measures to compensate in the manner prescribed by law for material damage, if they were caused to a citizen as a result of infringement of his rights or legitimate interests, to address the liability of persons for whom the violation was committed, as well as at the request of the citizen no later than one month the decision is made to the notice of the local self-government body, labour collective or association of citizens at the place of residence of the citizen, $\mathrm{etc}^{21}$.

${ }^{21}$ Про звернення громадян: Закон України від 02.10.1996 р. Дата оновлення 01.01.2020 p. URL: https://zakon2.rada.gov.ua/laws/show/393/96-\%D0\%B2\%D1\%80. 
The efficiency of the subject of power, as an indicator of their activity, reflects the activity, which is characterized by the full implementation, quality and within the statutory period of the tasks and responsibilities provided for the use of optimal resources (organizational, personnel, financial, information, etc.). When considering citizens' appeals, the subjects of power must adhere to the deadlines set by law. Thus, in accordance with Art. 20 of the Law of Ukraine «On Citizens' Appeals» appeals are considered and resolved within one month from the date of their receipt, and those that do not require additional study - immediately, but not later than fifteen days from the date of receipt. If it is impossible to resolve the issue specified in the appeal within a month, the head of the relevant body, enterprise, institution, organization or his deputy shall set the necessary deadline for its consideration, which shall be notified to the person who submitted the appeal. In this case, the total term for resolving the issues raised in the appeal may not exceed forty-five days.

Hence, the exercise of the right of citizens to appeal affects the effectiveness and efficiency of the subjects of power by providing information about their social needs, acting as a link between public authorities and citizens. The right to appeal to these bodies, on the one hand, is a way of expressing public opinion, and on the other - a means of obtaining information from the authorities about the quality and shortcomings of their work.

\section{CONCLUSIONS}

Trying to adapt the processes of democratization of governance to the European level, Ukraine has outlined a program of measures to introduce new forms of participation of civil society institutions in public administration. Among them, civil control over the activities of the subjects of public administration is not only an indicator of compliance with the principles of the rule of law and proper governance of the authorities, but is also an effective mechanism for ensuring human and civil rights and freedoms. Civil control over the activities of the subjects of public administration is defined as the activities of the public (individuals and (or) public associations), which consists in its active interaction with the subject of public administration through a system of observations and inspections to establish compliance with the state of an object that is subject to control by the applied instruments of public administration, and which is aimed at achieving the goal of proper provision of human and civil rights and freedoms in the field of public administration.

The emphasis is placed on the fact that forms of public participation in public administration, which are not supported by specific measures of legal 
responsibility, do not mediate the obligation to take into account public opinion de facto, and therefore are ineffective.

\section{SUMMARY}

The article is devoted to the study of the theoretical and legal foundations of civil control over the activities of public administration. There are such specific features that are inherent in civil control, as: the subject of civil control are citizens and public associations that are organizationally and functionally independent of the objects of control; the object of civil control is the sphere of public administration; the purpose of civil control is to ensure the public interest; civil control is exercised exclusively in the manner prescribed by law; provided by moral and legal measures of influence; the results of civil control may be the basis for other types of civil control provided by state coercion. The basic principles of functioning of the institute of citizens' appeals as a form of civil control over the activity of public administration subjects are analyzed.

\section{REFERENCES}

1. Угода про асоціацію між Україною, 3 однієї сторони, та Європейським Союзом, Європейським співтовариством 3 атомної енергії і їхніми державами-членами, 3 іншої сторони: Міжнародний документ від 27.06.2014 р. Дата оновлення від 30.11.2015 p. URL: https://zakon.rada.gov.ua/laws/show/984_011.

2. Про сприяння розвитку громадянського суспільства в Україні: Указ Президента України від 26.02.2016 р. № 68/2016. Дата оновлення від 26.02.2016 p. URL: https://zakon.rada.gov.ua/laws/show/68/2016.

3. Соляр С. Громадянське суспільство: загальнотеоретичні підходи до визначення. Вісник Академї правових наук України. 2013. № 1. Ст. 271-279.

4. Конституція України: Закон України від 02.10.1996 р. Із змінами, внесеними Законом України від 08.12.2004 р. № 2222-IV. Дата оновлення 01.01.2020 p. URL: http://zakon2.rada.gov.ua/laws/show/254\%D0\%BA/ 96-\%D0\%B2\%D1\%80.

5. Загальна декларація прав людини: Міжнародний документ від 10.12.1948 p. URL: http://zakon4.rada.gov.ua/laws/show/995_015.

6. Конвенція про захист прав людини і основоположних свобод: Міжнародний документ від 04.11.1950 p. URL: http://zakon2.rada.gov.ua/ laws/show/995_004.

7. Міжнародний пакт про громадянські i політичні права: Міжнародний документ від 16.12.1966 p. URL: https://zakon.rada.gov.ua/ laws/show/995_042. 
8. Хартія основних прав Свропейського Союзу: Міжнародний документ від 07.12.2000 p. URL: http://zakon2.rada.gov.ua/laws/show/994_524.

9. Про звернення громадян: Закон України від 02.10.1996 р. Дата оновлення 01.01.2020 p. URL: https://zakon2.rada.gov.ua/ laws/show/393/96-\%D0\%B2\%D1\%80.

10. Костюкевич О.К. Про функції права громадян на звернення. Право i Безпека. 2009. № 1. С. 195.

11. Про затвердження Інструкції з діловодства за зверненнями громадян в органах державної влади і місцевого самоврядування, об'єднаннях громадян, на підприємствах, в установах, організаціях незалежно від форм власності, в засобах масової інформації: Постанова Кабінету Міністрів України від 14.04.1997 № 348. URL: https://zakon.rada.gov.ua/ laws/show/348-97-\%D0\% BF.

12. Юридична енциклопедія: в 6 т. / за заг. ред. Ю.С. Шемшученко. Київ: «Укр. енцикл.», 2002. Т. 4: Н-П. 720 с. URL: http://leksika.com.ua/legal.

13. Кодекс адміністративного судочинства України: Закон України від 6.07.2005 р. № 2747-IV. Дата оновлення 13.02.2020 p. URL: https://zakon.rada.gov.ua/laws/show/2747-15/conv.

14. Цимбалюк В.М. Сутність права громадян на звернення до публічної адміністрації. Право і суспільство. № 2. 2012. С. 91.

15. Цимбалюк В.І., Кісілевич К.О. Звернення громадян як важлива складова захисту прав і свобод людини та громадянина в Україні. Молодий вчений. № 5.1 (45.1). 2017. С. 149-150.

16. Стеценко С.Г. Адміністративне право України. Навчальний посібник. Київ : Атіка, 2007. С. 123.

\section{Information about author:}

Maslova Ya. I., $\mathrm{PhD}$ in Law, Associate Professor at the Department of Administrative and Financial Law National University "Odesa Law Academy" 23, Fontanska doroha str., Odesa, 65009, Ukraine

Savchuk R. M., $\mathrm{PhD}$ in Law, Head of the Ivano-Frankivsk Law Institute of National University "Odesa Law Academy”, 13, Maksimovycha str., Ivano-Frankivsk, 76006, Ukraine 